\title{
An Assessment of the Dilution Required to Mitigate Hanford Tank 241-SY-101
}
J. D. Hudson
A. P. Larrick ${ }^{(a)}$
G. S. Barney ${ }^{(\mathrm{a})}$
D. A. Reynolds ${ }^{(a)}$
P. R. Bredt
C. W. Stewart
A. R. Felmy
J. M. Tingey
D. L. Herting ${ }^{(\mathrm{a})}$
D. S. Trent

February 1995

Prepared for

the U.S. Department of Energy

under Contract DE-AC06-76RLO 1830

Pacific Northwest Laboratory

Richland, Washington 99352

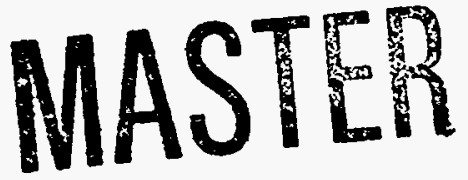

(a) Westinghouse Hanford Company 



\section{DISCLAIMER}

This report was prepared as an account of work sponsored by an agency of the United States Government. Neither the United States Government nor any agency thereof, nor any of their employees, make any warranty, express or implied, or assumes any legal liability or responsibility for the accuracy, completeness, or usefulness of any information, apparatus, product, or process disclosed, or represents that its use would not infringe privately owned rights. Reference herein to any specific commercial product, process, or service by trade name, trademark, manufacturer, or otherwise does not necessarily constitute or imply its endorsement, recommendation, or favoring by the United States Government or any agency thereof. The views and opinions of authors expressed herein do not necessarily state or reflect those of the United States Government or any agency thereof. 


\section{DISCLAIMER}

Portions of this document may be illegible in electronic image products. Images are produced from the best available original document. 


\section{Executive Summary}

A group of experts from PNL and WHC convened November 2 and 3, 1994, to screen the current state of knowledge about dilution and reach a consensus on the minimum dilution ratio that will achieve passive mitigation of Tank 241-SY-101 wastes and the dilution ratio that would satisfy the given cross-site transfer criteria with reasonable assurance. This report summarizes the findings, the discussion of the panel, and the technical basis for the final decision.

The panel evaluated the effects of dilution on the parameters important in gas generation, retention, and release and reached the following conclusions, which are deduced from the existing body of data, experience, and analyses:

- Dissolution of solids is the single most important aspect of mitigation by dilution. We are confident that diluting until nitrates, nitrites, and aluminum salts are dissolved will mitigate Hanford flammable gas tanks.

- Sufficient solids dissolution can be achieved in Tank 241-SY-101 at a dilution ratio of 1:1, which will result in a average specific gravity of approximately 1.35 . It is likely that a $0.5: 1$ dilution will also mitigate 241-SY-101, but the current uncertainty is too high to recommend this dilution ratio.

- The recommended dilution requires a diluent with at least 2 molar free hydroxide, because aluminum probably precipitates at lower hydroxide concentrations.

The transfer criteria for Tank 241-SY-101 waste were also evaluated. These criteria have been specified as solids content $\leq 30 \%$ (volume), viscosity $\leq 30 \mathrm{cP}$, and density $\leq 1.5 \mathrm{~g} / \mathrm{mL}$ (WHC 1993).

- Solids content is the limiting criterion if it is defined as volume fraction of settled solids. A $1: 1$ dilution will satisfy this criterion at nominal premixing conditions in Tank 241-SY-101; however, analysis of Window E core samples suggests that up to $1.5: 1$ might be required. If the solids content is interpreted simply as solids volume fraction no further dilution is necessary, because Tank 241-SY-101 waste (excluding the crust) is already below $30 \%$.

- Bulk density is the next limiting criterion and is met at $0.4: 1$ dilution. 



\section{Contents}

Executive Summary $\ldots \ldots \ldots \ldots \ldots \ldots \ldots \ldots \ldots \ldots \ldots \ldots \ldots \ldots \ldots \ldots \ldots \ldots$ iii

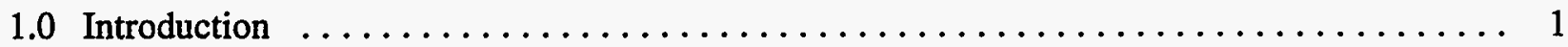

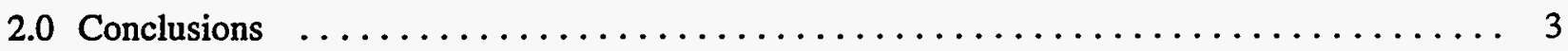

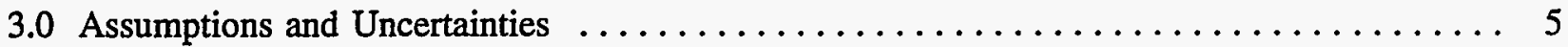

4.0 Evaluation Procedure $\ldots \ldots \ldots \ldots \ldots \ldots \ldots \ldots \ldots \ldots \ldots \ldots \ldots \ldots \ldots \ldots \ldots$

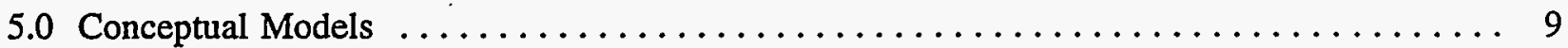

5.1 Neutral Buoyancy Model $\ldots \ldots \ldots \ldots \ldots \ldots \ldots \ldots \ldots \ldots \ldots \ldots$

5.2 Specific Gravity $<1.35$ Criterion $\ldots \ldots \ldots \ldots \ldots \ldots \ldots \ldots \ldots \ldots \ldots \ldots \ldots \ldots \ldots \ldots$

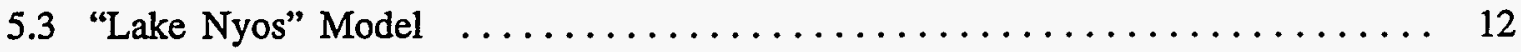

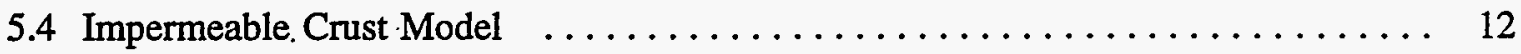

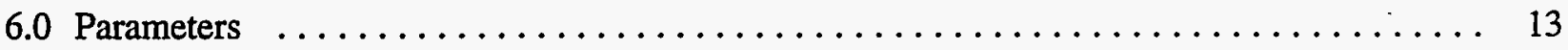

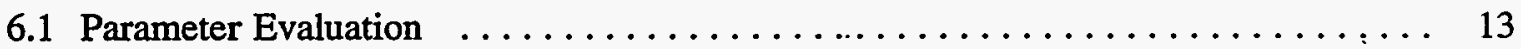

6.1.1 Particle Size and Density, Liquid to Sludge Density Ratio, and Surface
Tension $\ldots \ldots \ldots \ldots \ldots \ldots \ldots \ldots \ldots \ldots \ldots \ldots \ldots \ldots \ldots \ldots \ldots \ldots \ldots \ldots$

6.1.2 Yield Point and Viscosity of the Settled Slurry, Volume of Settled Solids,
Organics Concentration, Diffusion, Gas Generation Rate, and Bubble Rise . . . . 14

6.1.3 Temperature and Hydrostatic Head $\ldots \ldots \ldots \ldots \ldots \ldots \ldots \ldots \ldots \ldots$

6.1.4 Specific Gravity and Volume of Solids $\quad \ldots \ldots \ldots \ldots \ldots \ldots \ldots \ldots \ldots \ldots \ldots$

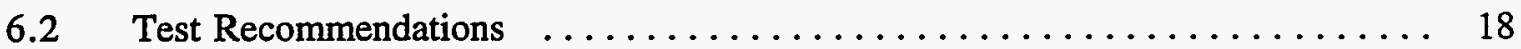

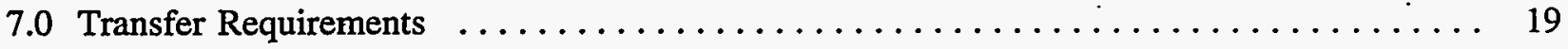

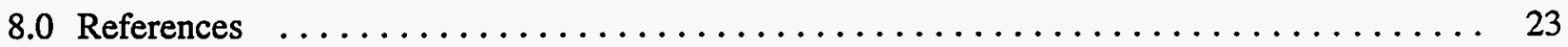




\section{Figures}

Figure 1. Schematic of Neutral Buoyancy Rollover Event $\ldots \ldots \ldots \ldots \ldots \ldots \ldots$

Figure 2. Specific Gravities of Flammable Gas Watch List Tanks $\ldots \ldots \ldots \ldots \ldots \ldots \ldots$

Figure 3. "Lake Nyos" Model $\ldots \ldots \ldots \ldots \ldots \ldots \ldots \ldots \ldots \ldots \ldots \ldots \ldots \ldots \ldots$

Figure 4. Dissolution of Tank $241-S Y-101$ Solids $\ldots \ldots \ldots \ldots \ldots \ldots \ldots \ldots \ldots \ldots$

Figure 5. Dissolution of Chemical Species with $2 \mathrm{M} \mathrm{NaOH}$ Dilution of Tank 241-SY-101

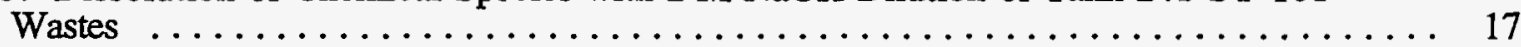

Figure 6. Viscosity of Tank 241-SY-101 High-Solids-Content Nonconvective Layer Samples When Diluted with $2 \mathrm{M} \mathrm{NaOH}$ Solution $\ldots \ldots \ldots \ldots \ldots \ldots \ldots \ldots \ldots \ldots \ldots$

Figure 7. Bulk Density of Tank 241-SY-101 Wastes Diluted with $2 \mathrm{M} \mathrm{NaOH}$ Solution ... . . . 20

\section{Tables}

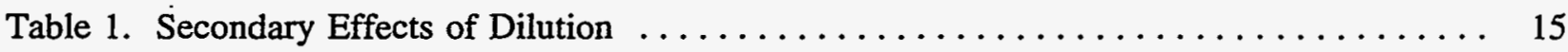

Table 2. Estimates of Settled Solids Volume for Transfer Criterion $\ldots \ldots \ldots \ldots \ldots \ldots \ldots$ 


\subsection{Introduction}

The term "mitigation," as applied to Hanford flammable gas waste tanks, can be defined as prevention of hazardous flammable gas releases. For Tank 241-SY-101, this requires keeping the tank in a state such that no gas release events (GREs) occur that result in the average hydrogen concentrations in the tank dome exceeding $25 \%$ of the lower flammability limit (LFL).

Mitigation methods can be described as active or passive. Active mitigation requires continued operation of some installed system, such as a mixer pump; passive mitigation does not, except for ancillary systems such as ventilation and monitoring, require such systems. Dilution is potentially a passive mitigation method unless active heating (of vent air or of the waste itself) becomes necessary to control waste temperature and keep solids in solution.

Dilution is one of the four leading concepts that were proposed for mitigating Hanford flammable gas tanks by the Mitigation and Remediation Concepts Working Group, which was established in July 1991 (Babad et al. 1992a). The state of knowledge on dilution as a mitigation method was considered at length in PNL's Assessment of Alternative Mitigation Concepts for Hanford Flammable Gas Tanks (Stewart et al. 1994). The conclusion of that report was that

\section{Existing data are not sufficient to prove that dilution can mitigate GRE behavior or to predict what dilution ratio is necessary... However, there are indications that practical dilutions (around 1:1) may eliminate gas retention...}

Although mitigation by dilution at a specific ratio has not be proven, it is clear that mitigation is ensured at some very high (though possibly impractical) dilution ratio. It is possible that the data and observed tank behavior will allow extrapolation from infinity to some much lower dilution ratio with a reasonable degree of confidence:

Future retrieval, processing, and ultimate disposal of the waste in tanks such as 241-SY-101 will require dilution. The dilution ratio determines the volume of new waste generated and therefore the additional tank capacity that must be provided. To plan for this, the Retrieval and Upgrades programs need a reasonable estimate of the dilution ratio required for transfer and passive mitigation by early 1995 .

In an atter:pt to provide part of this information, a group of experts from Pacific Northwest Laboratory (PNL) and Westinghouse Hanford Company (WHC) convened November 2 and 3, 1994. This "Graybeard" Panel was tasked with screening the current state of knowledge about dilution and reaching consensus on the dilution ratio less than infinity that might achieve passive mitigation and the dilution ratio that would satisfy the given cross-site transfer criteria with reasonable assurance. The Graybeard Panel participants were

from Pacific Northwest Laboratory:

from Westinghouse Hanford Company:
P. R. Bredt
A. R. Felmy
J. D. Hudson
C. W. Stewart
J. M. Tingey
D. S. Trent
G. S. Barney
D. L. Herting
A. P. Larrick
D. A. Reynolds

Because 241-SY-101 will benefit most from passive mitigation, and because most of the data were derived from 241-SY-101 waste, this tank was the focus of the investigation. This report summarizes the findings and discussions of the panel and the technical basis for their final decision. 



\subsection{Conclusions}

The objective of this study was to define a credible minimum dilution ratio such that no gas releases occur in Tank 241-SY-101 that result in the average dome hydrogen concentrations exceeding $25 \%$ of the LFL. The panel evaluated the effects of dilution on the parameters important in gas generation, retention, and release and reached the following conclusions from the resulting pool of data, experience, and analyses:

- Dissolution of solids is the single most important aspect of mitigation by dilution. The panel is confident that diluting until nitrates, nitrites, and aluminum salts are dissolved will mitigate Hanford flammable gas tanks.

- Sufficient solids dissolution can be achieved in Tank 241-SY-101 at a dilution ratio of 1:1, which will result in a average specific gravity of approximately 1.35 . It is likely that a $0.5: 1$ dilution will also mitigate $241-S Y-101$, but the current uncertainty is too high to recommend this dilution ratio.

- The recommended dilution requires a diluent with at least 2 molar free hydroxide, because aluminum probably precipitates at lower hydroxide concentrations.

The transfer criteria for Tank 241-SY-101 waste were also evaluated. These criteria have been specified as solids content $\leq 30 \%$ (volume), viscosity $\leq 30 \mathrm{cP}$, and density $\leq 1.5 \mathrm{~g} / \mathrm{mL}$ (WHC 1993).

- Solids content is the limiting criterion if it is defined as volume fraction of settled solids. A 1:1 dilution will satisfy this criterion at nominal premixing conditions in Tank 241-SY-101; however, analysis of Window $\mathrm{E}$ core samples suggests that up to $1.5: 1 \mathrm{might}$ be required. If the solids content is interpreted simply as solids volume fraction no further dilution is necessary, because Tank 241-SY-101 waste (excluding the crust) is already below $30 \%$.

- The solids content limit of $30 \%$ settled solids is evidently based on past practices and current operating limits. Relaxing this limit could significantly lower the required dilution ratios. To change this limit, the following information would be useful:

- What is the technical basis for this limit?

- How should the solids in the tank be interpreted to assess whether this limit can be met?

- How can solids content be measured in the pipeline?

- Bulk density is the next limiting criterion and is met at 0.4:1 dilution.

- Viscosity of the mixed waste can be reduced below $30 \mathrm{cP}$ with less than $0.15: 1$ dilution. 



\subsection{Assumptions and Uncertainties}

Studies of dilution in Hanford waste tanks immediately confront insufficiencies and conflicts in the data, and questions about relating the data to tank conditions. This creates considerable uncertainty in the conclusions; in fact, the data are insufficient to prove conclusively that any specific amount of dilution will mitigate hazardous flammable gas releases (Stewart et al. 1994). The following are some of the most important uncertainties concerning Tank 241-SY-101:

- It is not clear how to relate dilutions of laboratory samples to those required to achieve similar effects in the tank. Most test data were obtained from core samples from the sludge layer. Because the sludge represents approximately half the waste, the tank dilution ratio is ordinarily half the test dilution ratio. However, mixing the sludge with supernatant liquid has the effect of dilution for some properties. On the other hand, less of the solids dissolve in the preserice of a saturated supernatant liquid. Future dilution tests should use whole-tank composite samples to eliminate this problem.

- $\quad$ Operating the mixer pump for more than a year has quite clearly changed the waste configuration and properties. Virtually all existing dilution information is based on waste conditions before the current mixer pump was installed. Dilution would probably be more effective in the current waste, but no measurements have been made to confirm this. Data from the imminent operation of the Void Measurement Device and Ball Rheometer will update some of the information, but a fresh sample (not necessarily a full core) of actual waste in its current condition is needed.

- We simply do not know the mechanism of gas retention in the waste nor the parameters that control it. Therefore, it is not possible to predict the effect of dilution on gas retention. The preponderance of evidence that dilution can mitigate hazardous gas releases is indirect and circumstantial. Tests are planned at PNL in early 1995 to directly measure gas retention in Tank 241-SY.-101 waste as a function of dilution.

- We did not include the crust in the analysis for either mitigation or transfer. Including the crust will increase the dilution necessary for both mitigation and transfer, because the crust contains additional solids. But a 1:1 dilution probably provides sufficient margin to accommodate them. Also, most of the mixed slurry can probably be transferred without disturbing the crust. The question then would be how the crust dissolves when the tank is backfilled.

- We assumed dilution would be accomplished uniformly. This is a good assumption for in-line dilution of the material being transferred to a new tank, but probably not a good one for backfilling the donor tank. It may be difficult to mix all the solids with the diluent, and some volume may still be able to retain gas. The crust is also an issue here.

- We assumed no dissolution or precipitation occurs during transfer. The transit time in the pipeline is relatively short compared with the time.for dissolving solids. Some of the more soluble salts could be expected to dissolve in a long pipe run. We do not think that aluminum compounds will dissolve or precipitate during this time. On the other hand, viscosity values were determined from samples that had undergone significant dissolution.

- We did not consider the actual dilution procedure or the long-term effects of dilution (other than mitigation). We treated the hydrostatic head in the donor and receiver tanks and waste temperature as operational issues that could be controlled to avoid potential problems. 



\subsection{Evaluation Procedure}

The conclusions of this workshop were established by inference and consensus, not directly from analyses and data. It was clear that many parameters change dramatically over a rather narrow range of dilutions. But it was not clear that any of these changes would result in mitigation. The conclusions were possible only by establishing a preponderance of evidence from all sources. In order to do this effectively, we followed a logical procedure to extract and arrange the information. The details of the discussions and findings are given in this section. This is a brief outline of the sequence: .

- Define conceptual GRE models

- $\quad$ Select key processes in the models

- Select controlling parameters

- Determine limiting values of parameters for mitigation

- Find the corresponding dilution ratio for Tank 241-SY-101

- Determine the dilution ratio to satisfy transfer criteria for Tank 241-SY-101 waste.

The first task of the panel was to establish credible conceptual mechanisms for GRE behavior. To decide whether hazardous GREs can be mitigated, it is necessary to have a model of the behavior that describes causes and effects of the important processes and parameters involved. The models were required to be consistent with known Tank 241-SY-101 behavior and waste conditions as determined from tank data. An example of a conceptual model is the neutral buoyancy model (Stewart et al. 1994).

Given one or more conceptual models, we then selected the key process(es) in each model that determines whether GRE behavior occurs. Important processes in most models would be gas generation and gas retention. For example, if gas retention is eliminated, a large episodic gas release is not possible.

Within the framework of the selected models and processes, we determined parameters that influence the key processes. This was difficult, because the physical mechanisms for some of the most important processes are not known. Gas retention is the most notorious example. In some cases, the processes themselves were deemed to be parameters. Gas generation was one of these.

Given the list of controlling (or potentially controlling) parameters for mitigation by dilution, it was theoretically possible to decide the parameter values needed to mitigate Tank 241-SY-101 and what dilution ratio would yield those values. However, this also required that the panel agree on how the existing Tank 241-SY-101 dilution test data represent the current tank conditions. Only subjective judgments were possible when the physical mechanisms were unknown. As will be explained in detail below, the discussion finally focused on dissolution of the sodium and aluminum solids. We determined that dissolution of these solids is the key factor in mitigation, even though the actual mechanism is not known. After reaching this key conclusion, it was relatively easy to specify a dilution ratio to provide the required dissolution with reasonable confidence.

The final task of the panel was to obtain and document consensus on the dilution ratio needed to satisfy the cross-site transfer criteria for Tank 241-SY-101 waste. As it happened, this also required obtaining consensus on the interpretation of the solids content criterion and how to evaluate it from tank data. As the conclusion states, we questioned the technical basis of the criteria and recommended that the issue be reevaluated. 
We believe that we have included all the important aspects of flammable gas release behavior and considered all the important data and observations. We are confident that this study was thorough and that the conclusions represent a reasonable extrapolation of the current knowledge of the panel. 


\subsection{Conceptual Models}

Models of gas release behavior are required to provide a framework for deciding whether dilution has modified the behavior of the waste and at what point that might occur. For the purpose of this workshop, only conceptual models were considered (as opposed to formal computational or analytical models), because they were used mainly as a focus for discussion. Also, no satisfactory formal model exists to predict the effect of dilution on the gas release process. Four models were proposed in the discussion:

- Neutral buoyancy or Rayleigh-Taylor rollover model

- Empirical criterion that tank specific gravity $<1.35$

- "Lake Nyos" dissolved gas model

- Impermeable crust model.

Only the first two were retained for later analysis; each is discussed in some detail in this section.

\subsection{Neutral Buoyancy Model}

A GRE in a waste tank may be possible when enough gas accumulates in the sludge layer to make its density equal to that of the liquid above. The amount of gas released depends on the . volume of sludge that participates, the volume of gas required to make the sludge neutrally buoyant, and the hydrostatic pressure at which the gas is retained in the sludge. The gas volume depends on the ratio of liquid and sludge densities, and the hydrostatic pressure is proportional to both the average depth of the sludge below the waste surface and the average density. A GRE is assumed to occur when the sludge density becomes equal to the liquid density.

The neutral buoyancy model is consistent with the observed behavior of Tank 241-SY-101 and has been applied many times to explain rollovers (Allemann et al. 1991; Babad et al. 1992b), estimate bounding gas releases (LANL 1994, Appendix BC), and study the effects of dilution and drawdown (Stewart et al. 1994, Appendixes F and G). It was selected as the primary model for considering mitigation by dilution. The essence of the model is sketched in Figure 1 and described below.
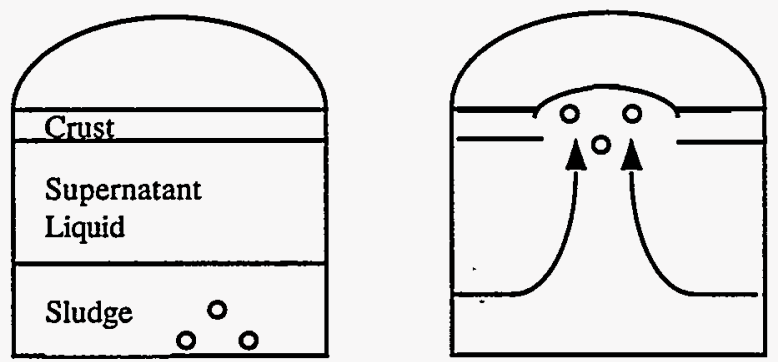

Figure 1. Schematic of Neutral Buoyancy Rollover Event 
The gas fraction, $\alpha_{\mathrm{NB}}$, required to make the sludge neutrally buoyant is given by

$$
\alpha_{\mathrm{NB}}=1-{\frac{\rho_{\mathrm{L}}}{\rho_{\mathrm{SL}}}}^{(\mathrm{a})}
$$

where $\rho_{\mathrm{L}}$ is the density of the liquid, $\rho_{\mathrm{SL}}$ is the density of the sludge, and the volume of gas actually stored in the sludge is

$$
\mathrm{V}_{\mathrm{GAS}}=\frac{\alpha_{\mathrm{NB}}}{1-\alpha_{\mathrm{NB}}} \mathrm{AD}
$$

where $A$ is the tank cross-sectional area and D is the thickness of the gas-retaining sludge layer. Note that one could also consider partial rollovers by letting $\mathrm{A}$ be a fraction of the total tank area and/or D be a portion of the total sludge thickness.

Assuming a GRE occurs at the neutral buoyancy point, the gas will rise to the surface, expanding by the ratio of its original hydrostatic pressure to ambient pressure. Gas is released to bring the sludge back to neutral buoyancy at the surface pressure. The effect of sludge yield strength is not included, because the mechanism for its effect is not known. The gas release volume is given by

$$
\mathrm{V}_{\mathrm{REL}}=\mathrm{V}_{\mathrm{GAS}}\left(\frac{\mathrm{P}_{\mathrm{H}}}{\mathrm{P}_{0}}-1\right)
$$

where $\mathrm{P}_{0}$ is the ambient pressure and $\mathrm{P}_{\mathrm{H}}$ the hydrostatic pressure. The hydrostatic pressure at the average sludge depth is

$$
P_{H}=\left[\rho_{C} C+\rho_{L} L+\frac{1}{2} \rho_{S L} D\right] g+P_{0}
$$

$\mathrm{C}, \mathrm{L}$, and D are the thickness of the crust, supernatant liquid, and gas-retaining sludge, respectively, with the corresponding densities. Combining Equations (1) through (4) yields the overall expression for gas release

$$
V_{\text {REL }}=\left[\frac{\rho_{\text {SL }}}{\rho_{\mathrm{L}}}-1\right]\left[\rho_{C} C+\rho_{L} L+\frac{1}{2} \rho_{S L} D\right] \frac{A D g}{P_{0}}
$$

where $\mathrm{g}$ is the gravitational acceleration.

According to this model, gas releases can be eliminated only by making the sludge and liquid densities equal or by making the sludge thickness zero. Both can be achieved by dissolving all the solids, which is not feasible. Gas release could also be eliminated by destroying the ability of settled solids to retain gas. Thus the key process for mitigation in the neutral buoyancy model is gas retention.

(a) Considering the gas density as negligible compared with the solids and liquid. 


\subsection{Specific Gravity $<1.35$ Criterion}

This is not so much a model as an observation of the behavior of all Flammable Gas Watch List Tanks. When these tanks are listed in the order of their average specific gravity, only those that exceed about 1.35 specific gravity exhibit any kind of GRE behavior, as shown in Figure 2 (Stewart et al. 1994). The ' $\mathrm{X}$ ' in the figure indicates that the tank has shown level growth, level drop, or some other indication of a potential or actual episodic GRE.

There is very little knowledge of the actual contents of the various tanks. Even the specific gravity itself is derived from fill history rather than measurements. Therefore the correlation between specific gravity and GRE behavior is neither clear nor certain. However, the observation was carried forward as an empirical criterion.

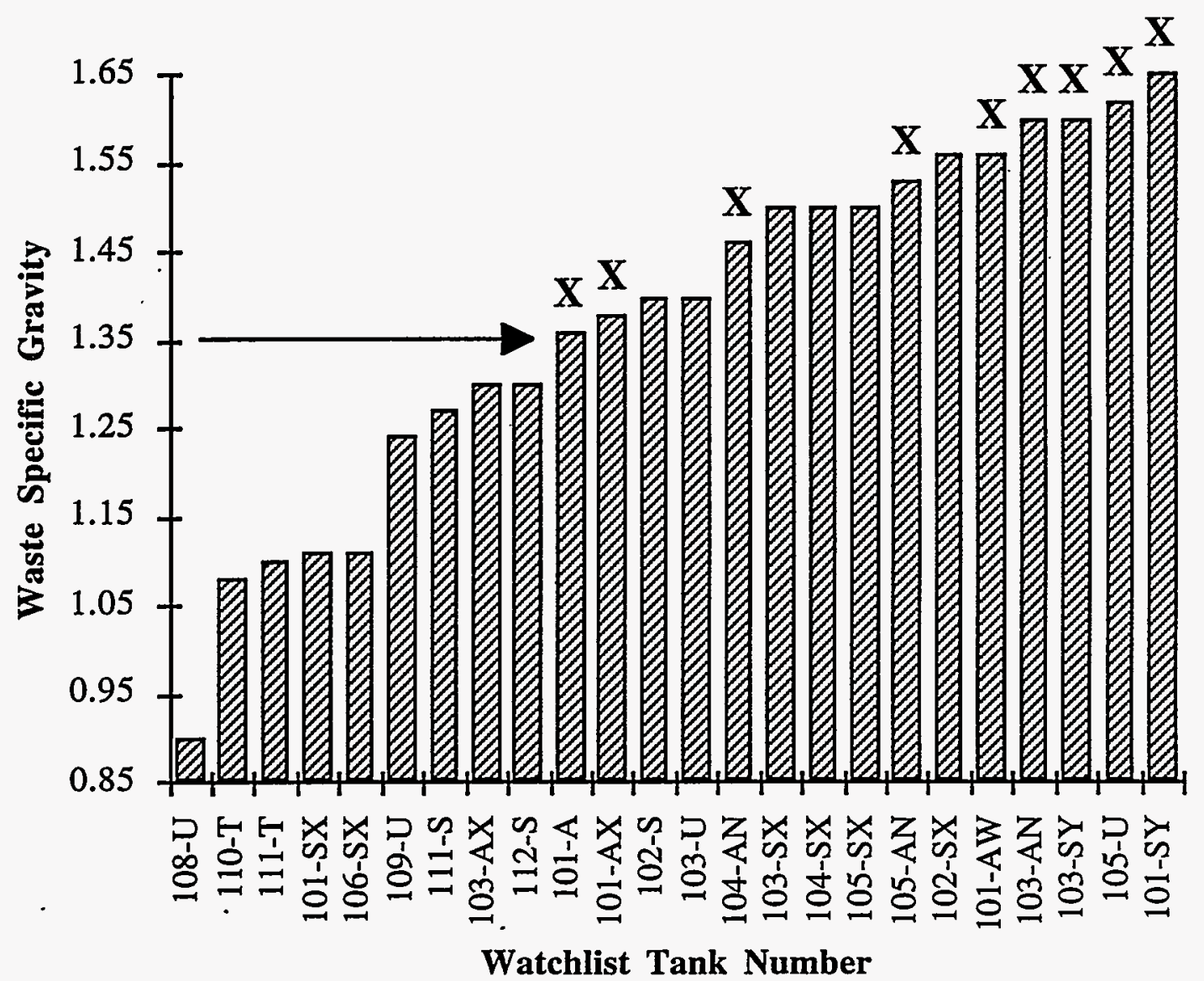

Figure 2. Specific Gravities of Flammable Gas Watch List Tanks 


\section{3 "Lake Nyos" Model}

In August 1986, a large volume of dissolved $\mathrm{CO}_{2}$ was released from Lake Nyos in Cameroon. The lake apparently foamed like a carbonated beverage, releasing a lethal cloud of gas and causing a flood of water in the drainage river. This was evidently caused by supersaturation of the lower layers of the lake by hot $\mathrm{CO}_{2}$ issuing from volcanic vents.

This model, shown schematically in Figure 3, was proposed earlier as a possible mechanism for GREs in Tank 241-SY-101. However, it was discarded after calculations showed that dissolved hydrogen and nitrous oxide would only account for a few hundred cubic feet of gas release, far short of the several thousand typically observed (Allemann et al. 1992). The panel rejected this model for the same reason.

\subsection{Impermeable Crust Model}

In this model, the crust layer seals the upper layers of the waste to gas release, allowing a large bubble to form beneath it. When the gas bubble grows large enough to lift the crust and fracture it structurally, the gas is suddenly released. This model was quickly rejected, because it was inconsistent with the changes in vertical temperature profiles in the tank before and after a GRE that show conclusively that material is brought up from the lower layers. Videos of the crust surface during a rollover also do not show any evidence of this mechanism.
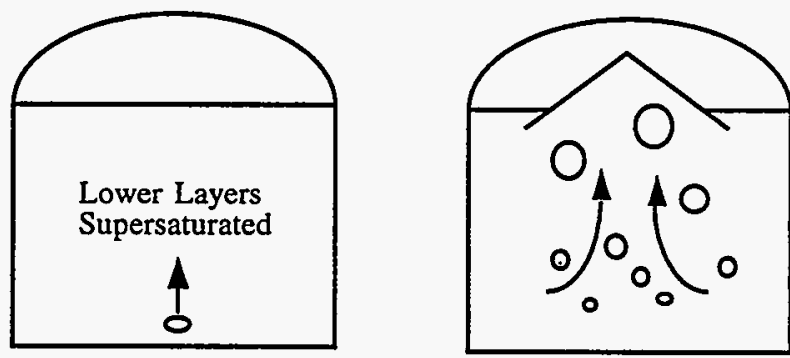

Figure 3. "Lake Nyos" Model 


\subsection{Parameters}

From the discussion of models, a set of parameters was developed that seem to affect or (in some cases) control gas release behavior. The list of parameters included

- $\quad$ Yield point of the settled slurry

- Viscosity of the settled slurry

- Particle size, shape

- Particle density

- Solids weight fraction

- Organics concentration

- Gas generation rate

- Volume of settled solids (packing efficiency)

- Temperature

- Density ratio of supernatant fluid to sludge

- Hydrostatic head

- $\quad$ Surface tension

- Surface diffusion

- Bubble rise behavior

- Average tank specific gravity.

\subsection{Parameter Evaluation}

The discussion on each of these parameters focused on the effects dilution would have and the quantification of the behavior that was possible. Several parameter groupings are apparent from this discussion, as will be discussed in subsequent sections. But first, the interpretation of the dilution ratio needs to be discussed.

Dilution is quantified by the ratio of the volume of diluent to the original waste volumes. For example, a ratio of $0.5: 1$ (diluent:waste), or a 0.5 dilution fraction, represents adding $5 \mathrm{~mL}$ of diluent to $10 \mathrm{~mL}$ of waste. However, the basis of the dilution ratio needs to be corrected to relate laboratory test results from dilutions of core samples to dilutions that would have similar effects in the entire tank. Prior to mixing, about half the contents of Tank 241-SY-101 were nonconvective sludge (about 200 inches $[5 \mathrm{~m}]$ out of just over 400 inches $[10 \mathrm{~m}]$ of total waste). This means that a core sample of nonconvective material represents $1 / 2$ of the tank's original contents, and test dilutions need to be divided by correction factor of 2.0 to represent the tank. Therefore, a 1:1 dilution of the sludge core sample in a hot cell test would be equivalent to a $0.5: 1$ dilution of the entire tank.

During the workshop, J.M. Tingey (PNL) calculated that the exact correction factor for dissolution of solids actually. ranges from approximately 1.3 for small dilutions to the nominal 2.0 above about $2: 1$ test dilution (1:1 tank dilution). The correction is nonlinear because the convective layer material is saturated with many of the solid constituents, and small dilutions cause relatively less dissolution. However, for other properties, a 2.0 correction factor is probably adequate for all dilutions, but with substantial uncertainty (see Section 3.0).

We have attempted to define the dilution ratio explicitly in the discussion that follows. For example, 0.5:1 (2 M NaOH : nonconvective sample) is a hot cell test in which sample material from the nonconvective layer was diluted at. $0.5: 1$ with $2 \mathrm{M} \mathrm{NaOH}$. Otherwise, the context should make the intended dilution ratio clear. 


\subsubsection{Particle Size and Density, Liquid to Sludge Density Ratio, and Surface Tension}

Particle size and density, liquid to sludge density ratio, and surface tension are not thought to have a significant impact on how the gas retention behavior changes with dilution. Particle size will likely decrease as the sodium nitrate crystals dissolve, but it is unclear how this will affect gas retention. Similarly, particle density will increase as the lower density ionic salts dissolve and the insoluble metal (more dense) component remains in the solid phase. The liquid-to-sludge density ratio will not change significantly at low to moderate dilution ratios; therefore, its impact on gas retention should be limited.

Surface tension should decrease with dilution as the ionic strength of the solution decreases. Also, ammonia should be more soluble in the lower ionic strength solution, resulting in higher ammonia concentrations and thus lower surface tension. This decreasing surface tension should result in a sludge with less cohesion and, possibly, less ability to retain gas. However, the surface tension is not likely to drop by more than 30 to $40 \%$; thus, it will also have a limited impact.

\subsubsection{Yield Point and Viscosity of the Settled Slurry, Volume of Settled Solids, Organics Concentration, Diffusion, Gas Generation Rate, and Bubble Rise}

The effects of dilution on yield point and viscosity of the settled slurry, volume of settled solids, organics concentration, diffusion, gas generation rate, and bubble rise are thought to be beneficial, while quantification of the effects is not possible with the currently available data. Where available data allowed, inferences were drawn to suggest behavior regimes. The results are summarized in Table 1.

\subsubsection{Temperature and Hydrostatic Head}

These two parameters are considered operational variables. While the temperature of the waste will drop due to the lower volumetric radiolytic heating, temperature is considered an operational variable in that it may be controlled by either reducing the ventilation flow rates or using an external heat source.

Similarly, while the hydrostatic head increases with in-tank dilution, it is thought to be an operational variable because waste may be removed to other storage and/or processing facilities. In any case, Tank 241-SY-101 is full, and therefore the hydrostatic head will not increase much.

\subsubsection{Specific Gravity and Volume of Solids}

Specific gravity and volume of solids are thought to be the most critical parameters in predicting which wastes will exhibit episodic gas release behavior.

D. A. Reynolds (WHC) has reviewed the data from the Flammable Gas Watch List (FGWL) tanks to determine which parameters can be correlated to episodic gas release behavior. After examining a variety of data, he points out that (as shown in Figure 2) none of the FGWL tanks that have a (bulk) specific gravity below 1.35 demonstrate episodic gas release behavior. Most of those with specific gravities above 1.41 do show this behavior. Furthermore, he points out that evaporator slurries with specific gravities below 1.30 have relatively low viscosities and few or no solids, while those with specific gravities above 1.35 had much higher viscosities and solids fractions.

While the evidence for this observation is empirical, it constitutes the only data that are currently available for most of the FGWL tanks that seem to correlate well with episodic gas release behavior. The dilution ratio (with $2 \mathrm{M} \mathrm{NaOH}$ as a diluent) required to decrease the specific gravity of Tank 241-SY-101 to 1.41 is $0.72: 1$; to decrease it further to 1.35 requires about $1: 1$ dilution. 
Table 1. Secondary Effects of Dilution

\begin{tabular}{||l|l|l||}
\hline Parameter & $\begin{array}{l}\text { Effect of } \\
\text { Dilution }\end{array}$ & Available Data / Impact \\
\hline $\begin{array}{l}\text { Yield point of } \\
\text { settled slurry }\end{array}$ & $\begin{array}{l}\text { Significantly } \\
\text { decreases }\end{array}$ & $\begin{array}{l}\text { Tingey et al. (1994) data on the mixed slurry that results from } \\
\text { dilution of nonconvective layer samples with 2 M NaOH). } \\
\text { Significant decrease observed @ 0.2:1 (2 M NaOH) }\end{array}$ \\
\hline $\begin{array}{l}\text { Viscosity of } \\
\text { settled slurry }\end{array}$ & $\begin{array}{l}\text { Significantly } \\
\text { decreases }\end{array}$ & $\begin{array}{l}\text { Tingey et al. (1994) data on the mixed slurry that results from } \\
\text { dilution of nonconvective layer samples with 2 M NaOH). } \\
\text { Significant decrease observed @ 0.2:1 (2 M NaOH) }\end{array}$ \\
\hline $\begin{array}{l}\text { Volume of } \\
\text { Settled solids }\end{array}$ & $\begin{array}{l}\text { Significant } \\
\text { decreases } \\
\text { observed at } \\
\text { moderate to } \\
\text { high dilutions }\end{array}$ & $\begin{array}{l}\text { Tingey et al. (1994) and Bredt (Stewart et al. 1994) data on the } \\
\text { mixed slurry which results from dilution of nonconvective layer } \\
\text { samples with 2 M NaOH. Significant decrease observed in the } \\
\text { range of 0.5:1 to 1:1 (2 M NaOH) dilution rates. The effects of } \\
\text { this behavior on gas retention are unclear. }\end{array}$ \\
\hline $\begin{array}{l}\text { Organics } \\
\text { concentration }\end{array}$ & Decreases & $\begin{array}{l}\text { Concentration decrease is not linear because some organic } \\
\text { solids will enter the solution upon dilution; however, dilution is } \\
\text { thought to be beneficial because organics are tied to gas } \\
\text { generation and (possibly) retention. }\end{array}$ \\
\hline $\begin{array}{l}\text { Surface } \\
\text { diffusion } \\
\text { mechanisms }\end{array}$ & $\begin{array}{l}\text { Surface diffusion will increase relative to the amount of } \\
\text { organics and radioisotopes. Viscosity also decreases, which } \\
\text { improves thermal convection and brings fresh material to the } \\
\text { surface. This points to higher surface diffusion rates. }\end{array}$ \\
\hline $\begin{array}{l}\text { Gas generation } \\
\text { rate }\end{array}$ & $\begin{array}{l}\text { Decreases on } \\
\text { a per volume } \\
\text { basis }\end{array}$ & $\begin{array}{l}\text { Generation rate is tied to organics concentration and the } \\
\text { concentration of radioisotopes, both of which will decrease with } \\
\text { dilution. }\end{array}$ \\
\hline $\begin{array}{l}\text { Bubble rise } \\
\text { behavior }\end{array}$ & $\begin{array}{l}\text { Increases } \\
\text { rilution decreases the viscosity of the slurry; therefore, gas } \\
\text { mixture. bubble rise will be faster in a lower viscosity slurry . }\end{array}$ \\
\hline \hline
\end{tabular}

Though detailed chemical analyses are not available on all of the tanks that may be mitigated, solubility and dissolution models that predict the phase behavior of the chemical species will be valuable in predicting changes in the gas retention and release behavior that are likely to occur with dilution. These models are based on data from real waste and chemical simulant studies. Experimental data are available on real waste samples from Tank 241-SY-101.

Data and curves for the dissolution of Tank 241-SY-101 wastes are given in Figure 4. In this figure, the solid curve presents the best estimate of the dissolution of solids using $2 \mathrm{M} \mathrm{NaOH}$ as a diluent. The dashed line indicates an approximate dissolution curve with water as the reference diluent. These curves are approximations based on the compositions reported from the 1991 Tank 241-SY-101 samples (Herting et al. 1992a,b) and are shown with the variety of solubility data available from real waste and simulant studies. The data points from Tingey et al. (1994) and from Bredt (Stewart et al. 1994) were obtained from dilutions of nonconvective layer (high solids content) material. Thus the dilution ratios for these data are divided by a correction factor of 2 to be consistent with tank dilution. 


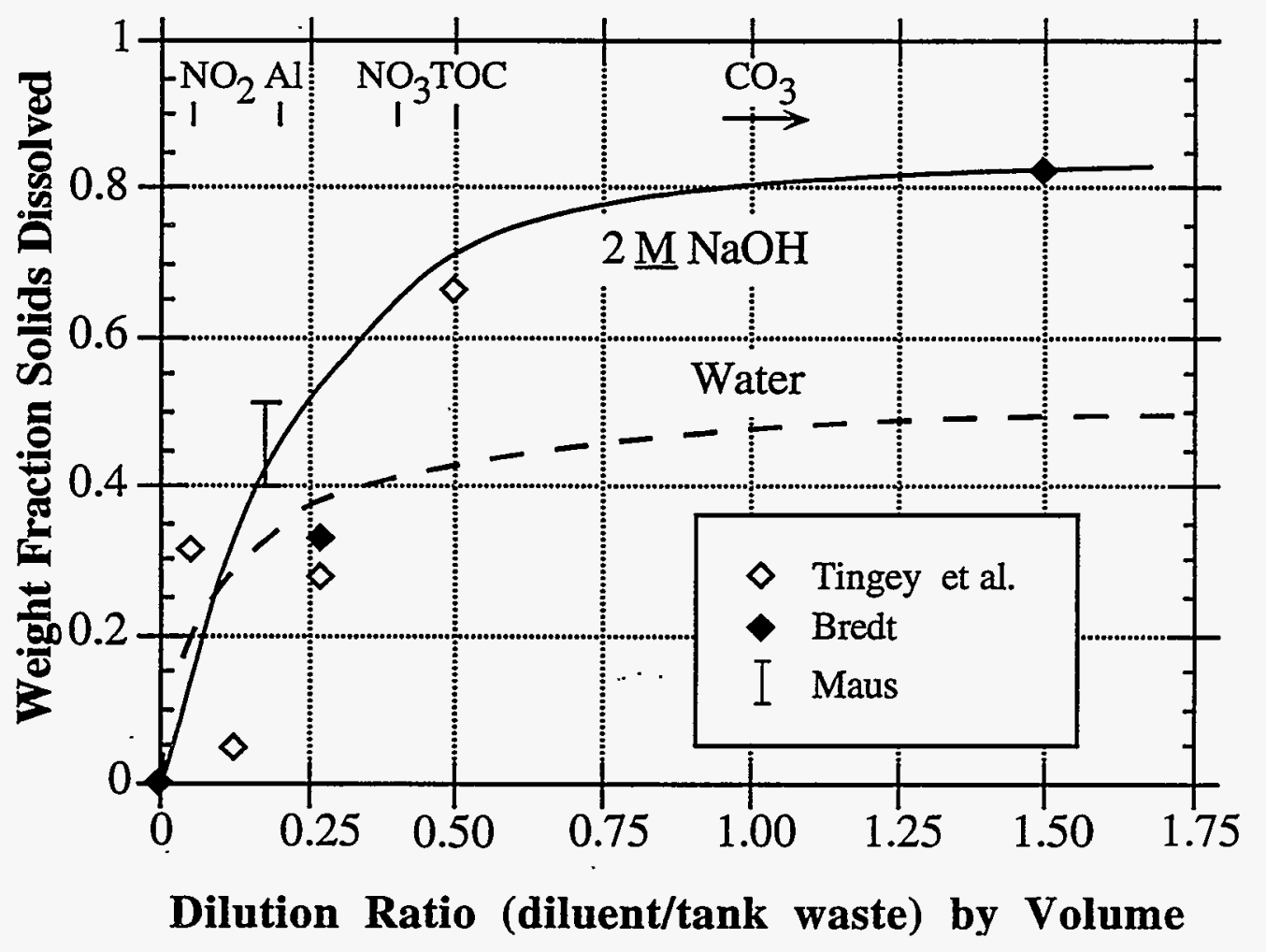

Figure 4. Dissolution of Tank 241-SY-101 Solids

The curves in Figure 4 indicate that a large fraction of solids dissolve by a dilution ratio of $0.5: 1$ and that dilution above $1: 1$ will result in very little additional dissolution. The markers at the top of the graph indicate approximately where the particular ions disappear from the solid phase (using $2 \mathrm{M} \mathrm{NaOH}$ as the diluent). (The total organic carbon [TOC] label refers here to the soluble organics, and the arrow by $\mathrm{CO}_{3}$ indicates that solid carbonates are still present beyond 1:1 dilution.) The same information is presented in a different form $\mathrm{r}_{2}$ in Figure 5. This figure shows the dissolution of each specie as a function of dilution for a Tank 241-SY-101 composite. From this, it is apparent that nitrite, sodium aluminate, and nitrate are completely dissolved by dilution at $0.3: 1.0$. At dilutions above $0.3: 1$, oxalate (soluble organics) and carbonate continue to dissolve but the effects of dilution on solids dissolution diminish at even higher dilution ratios (see Figure 4).

In all of this solubility information, the solids content of the crust layer is not considered. The actual dilution ratio required to dissolve the crust solids will be somewhat larger than that indicated in Figures 4 and 5. However, we believe that the conservatism in recommending the 1:1 dilution ratio is sufficient to absorb this error.

Based on this information, the panel concluded that the dilution ratio required to mitigate episodic gas release behavior is that needed to dissolve most of the soluble solids (i.e., the nitrate, nitrite, and aluminate). In the case of Tank 241-SY-101, this points to a dilution ratio in the range of $0.5: 1$ to $1: 1$. This dilution range is also that required to reduce the (bulk) specific gravity to the range of 1.35 to 1.41 . 


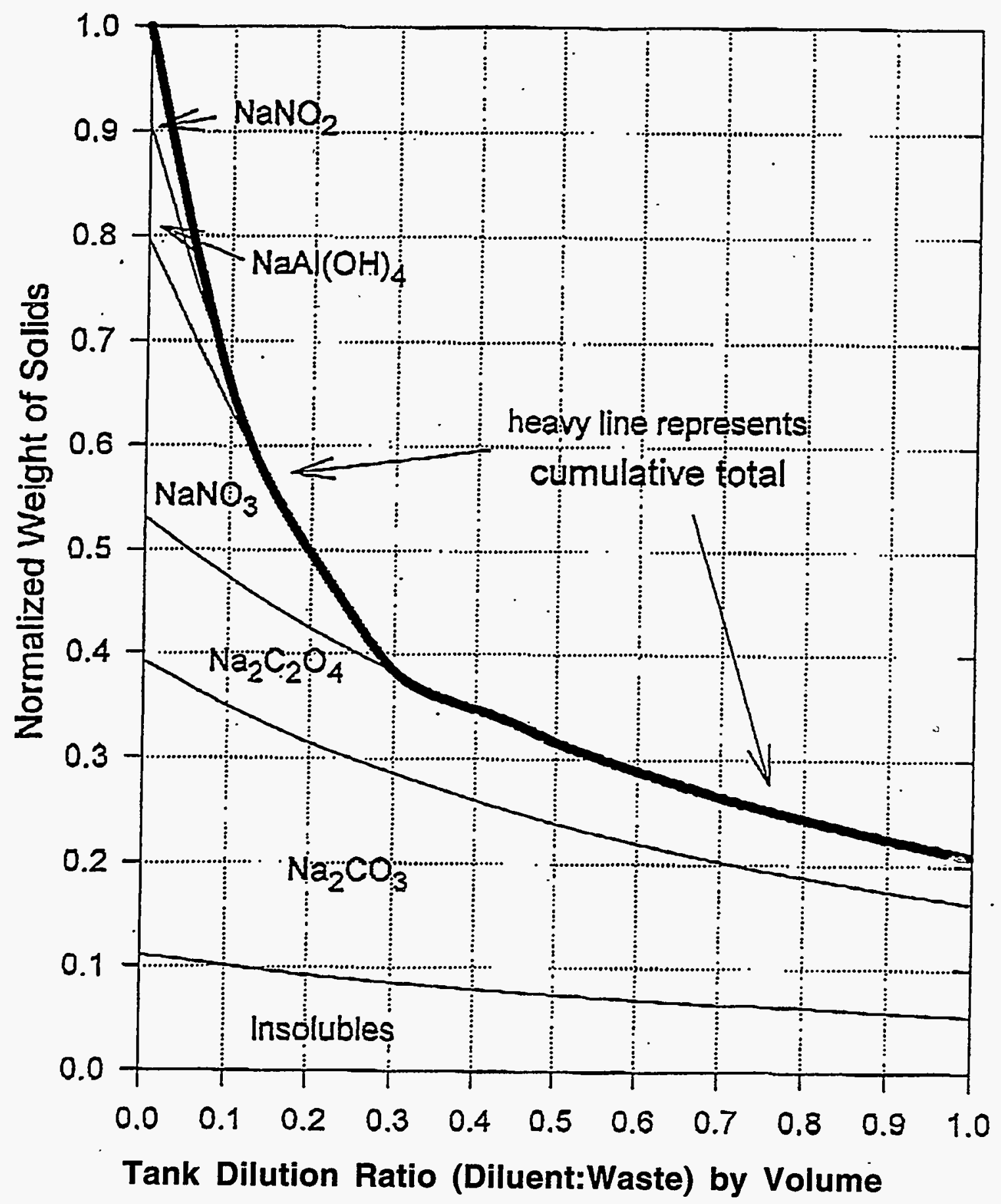

Figure 5. Dissolution of Chemical Species with $2 \underline{\mathrm{M}} \mathrm{NaOH}$ Dilution of Tank 241-SY-101 Wastes 


\subsection{Test Recommendations}

From these discussions, it seems clear that a 1:1 dilution would effectively mitigate the episodic gas release behavior observed in Tank 241-SY-101 prior to the mixer pump installation. Furthermore, there is evidence that a lower dilution ratio, perhaps as low as $0.5: 1$, will also mitigate. Because of this, we recommend that future dilution testing on Tank 241-SY-101 waste focus on the range of dilutions from $0.5: 1$ to $1: 1$ to confirm and clarify the minimum dilution ratio that will achieve passive mitigation. Finally, because there is a complete dearth of direct measurements of gas retention, we recommend that characterization of the dilution-related effects on gas retention behavior be measured and reported with a focus in this range of dilution ratios. 


\subsection{Transfer Requirements}

A secondary objective of the meeting of the Greybeard panel was to determine the minimum dilution required to meet the transfer criteria specified in the Functional Design Criteria for Project W-058, Replacement of Cross-Site Transfer System (WHC 1993). According to this document, the waste must have a bulk density less than $1.5 \mathrm{~g} / \mathrm{cc}$, viscosity below $30 \mathrm{cP}$, and a solids content less than $30 \%$ (volume).

Among the criteria, the viscosity requirement is easily defined and requires only a small dilution ratio to achieve. From the data of Tingey et al. (1994) (as shown in Figure 6), the viscosity of nonconvective waste sample diluted with $2 \mathrm{M} \mathrm{NaOH}$ requires a dilution ratio of less than $0.2: 1$ to give viscosities below $30 \mathrm{cP}$. It is again noted that the experiments of Tingey et al. diluted the highsolids content, nonconvective layer material; therefore, dilution of the currently mixed waste will require an even lower dilution ratio to meet this requirement.

The bulk specific gravity is also easily calculated from the information presented by Herting et al. (1992), Tingey et al. (1994), and Bredt (Stewart et al. 1994). As shown in Figure 7, the bulk density of Tank 241-SY-101 wastes falls beneath $1.5 \mathrm{~g} / \mathrm{cc}$ with a dilution ratio of $0.4: 1$ (2 $\mathrm{M} \mathrm{NaOH}$ to tank waste excluding crust).

What is meant in this set of criteria by the solids content of the waste is more difficult to define. If it is taken to be a volume fraction of the solids that excludes all liquids (including the interstitial liquid in the nonconyective layer), then the requirement is met with no dilution! Similarly, if it is taken to be a mass fraction of the solids that excludes all liquids, then the requirement is met with little or no dilution. In either of these cases, the bulk density is the limiting criterion, and the tank dilution required for transfer is $0.4: 1$.

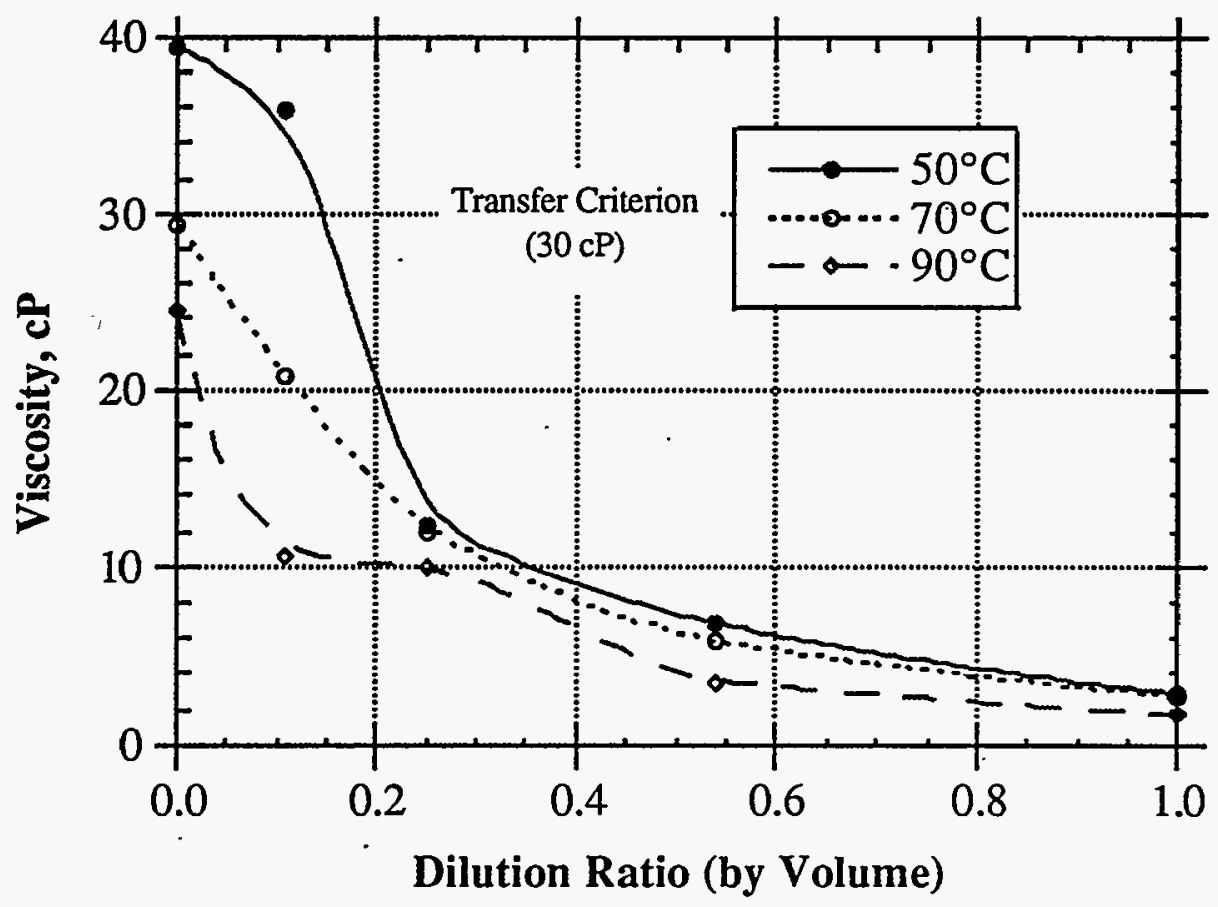

Figure 6. Viscosity of Tank 241-SY-101 High-Solids-Content Nonconvective Layer Samples When Diluted with $2 \mathrm{M} \mathrm{NaOH}$ Solution (data from Tingey et al. 1994) 


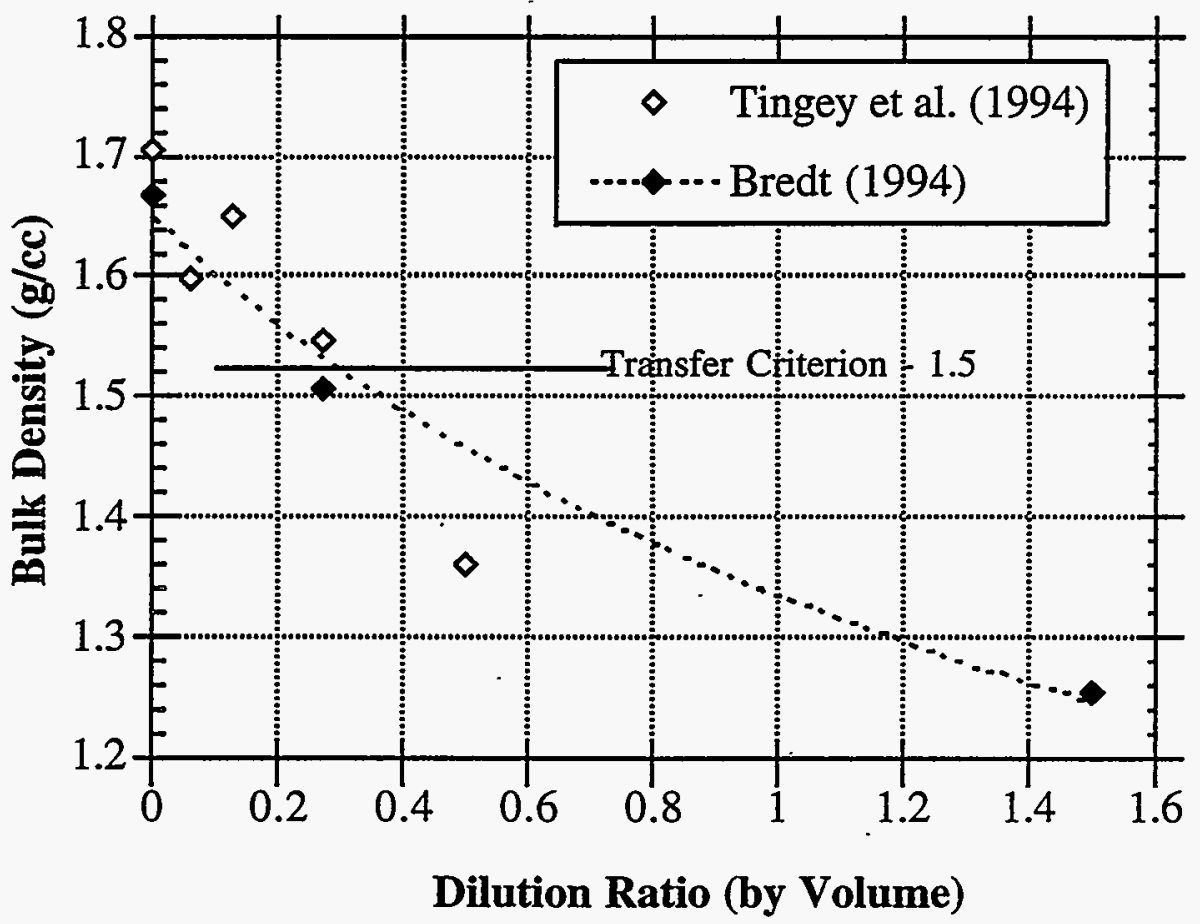

Figure 7. Bulk Density of Tank 241-SY-101 Wastes Diluted with $2 \mathrm{M}$ NaOH Solution (data of Tingey et al. (1994) and Bredt (Stewart et al.) obtained by dilution of nonconvective layer samples, corrected to account for the current mixed slurry condition [which contains both supernatant liquid and nonconvective layer material])

If, however, the solids content is taken to be the volume fraction of the settled slurry (which includes the interstitial liquid in the slurry), then this is the limiting criterion; and a much higher dilution ratio is required for transfer. For a first-order approximation, consider the layered waste configuration that was observed in Tank 241-SY-101 prior to pump installation. At that time, the crust layer was approximately $1 \mathrm{~m}$ thick, the predominantly liquid (convective) layer and the settled slurry (nonconvective) layer were each approximately $4 \mathrm{~m}$ thick, and a bottom sludge layer was approximately $1 \mathrm{~m}$ thick. If the settled slurry can be taken simply as that which occurred in the tank (i.e., prior to pump installation), then the solids content of the waste at 1:1 dilution is summarized in Table 2.

This assumption is optimistic in that the layered waste configuration requires long settling times (i.e., months), which are not planned to occur prior to transfer of the Tank 241-SY-101 wastes. A more conservative estimate is acquired using the data from the both the Windows $C$ and $E$ samples (Herting et al. 1992a,b) and assuming that no dissolution occurs within the time scales of the transfer process. This assumption is valid, because laboratory tests indicate that several hours are required to obtain dissolution. From these, the solids content that results from a $1: 1$ dilution with $2 \mathrm{M} \mathrm{NaOH}$ is approximately 40 to $45 \%$ (when the solids from the crust are included). To lower this to $30 \%$ requires a dilution ratio of approximately $1.5: 1$.

In performing this exercise, the need for a well-documented technical basis for this requirement becomes very clear. This basis should include a definition of the term solids content and a description of how it will be measured before as well as on-line during the transfer processes. If a 
relaxation of this restriction becomes feasible in the course of developing the technical basis (particularly for this transfer process, which will involve a relatively short distance compared with the cross-site transfers), a significantly lower dilution ratio may be possible. However, if the solids content is defined as the settled solids volume (which includes the interstitial liquid), it is the limiting criterion, and a dilution of 1.5:1 may be required.

Table 2. Estimates of Settled Solids Volume for Transfer Criterion

\begin{tabular}{||c|c|c|}
\hline Solids entering slurry & Settled solids with no dilution & Settled solids at 1:1 dilution \\
\hline \hline Slurry, sludge and crust & $6 \mathrm{~m} / 10 \mathrm{~m}=60 \%$ & $30 \%$ \\
\hline Slurry and sludge & $5 \mathrm{~m} / 9 \mathrm{~m}=56 \%$ & $28 \%$ \\
\hline Slurry only & $4 \mathrm{~m} / 8 \mathrm{~m}=50 \%$ & $25 \%$ \\
\hline
\end{tabular}




\subsection{References}

Allemann, R. T., Z. I. Antoniak, J. R. Friley, C. E. Haines, L. M. Liljegren, and S. Somasundaram. 1991. Mechanistic Analysis of Double-Shell Tank Gas Release: Progress Report - November 1990. PNL-7657, Pacific Northwest Laboratory, Richland, Washington.

Allemann, R. T., Z. I. Antoniak, L. L. Eyler, and L. M. Liljegren. 1992. Conceptual Models for Waste Tank Mechanistic Analysis: Status Report - January 1991. PNL-8011, Pacific Northwest Laboratory, Richland, Washington.

Babad, H., J. L. Deichman, B. M. Johnson, D. K. Lemon, and D. M. Strachan. 1992a.

Mitigation/Remediation Concepts for Hanford Site Flammable Gas-Generating Waste Tanks. WHCEP-0516, Westinghouse Hanford Company, Richland, Washington.

Babad, H., G. D. Johnson, and D. A. Reynolds. 1992b. Understanding the Cyclic Venting

Phenomena in Hanford Site High-Level Waste Tanks: The Evaluation of Tank 241-SY-101. WHCSA-1364-FP, Westinghouse Hanford Company, Richland, Washington.

Herting, D. L., D. B. Bechtold, B. A. Crawford, T. L. Welsh, and L. Jensen. 1992a. Laboratory Characterization of Samples Taken in May 1991 from Hanford Waste Tank 241-SY-101. WHC-SDWM-DTR-024 Rev. 0, Westinghouse Hanford Company, Richland, Washington.

Herting, D. L., D. B. Bechtold, B. E. Hey, B. D. Keele, T. L. Welsh, and L. Jensen. 1992b. Laboratory Characterization of Samples Taken in December 1991 (Window E) from Hanford Waste Tank 241-SY-101. WHC-SD-WM-DRT-026 Rev. 0, Westinghouse Hanford Company, Richland, Washington.

Los Alamos National Laboratory. 1994. A Safety Assessment for Proposed Pump Mixing Operations to Mitigate Episodic Gas Releases in Tank 241-SY-101: Hanford Site, Richland, Washington. LAUR-92-3196 Rev 12, LANL, Los Alamos, New Mexico.

Stewart, C. W., L. A. Schienbein, J. D. Hudson, E. J. Eschbach, and D. L. Lessor. 1994. Assessment of Alternative Mitigation Concepts for Hanford Flammable Gas Tanks. PNL-10105, Pacific Northwest Laboratory, Richland, Washington.

Tingey, J. M., P. R. Bredt, and E. H. Shade. 1994. The Effects of Heating and Dilution on the Rheological and Physical Properties of Tank 241-SY-101 Waste. PNL-10198, Pacific Northwest Laboratory, Richland, Washington.

Westinghouse Hanford Company. 1993. Functional Design Criteria for Project W-058, Replacement of Cross-Site Transfer System. WHC-SD-W058-FDC-001 Rev. 1, WHC, Richland, Washington. 


\section{Distribution}

No. of

Copies

OFFSITE

12 DOE Office of Scientific and Technical Information

3 Los Alamos National Laboratory

P.O. Box 1663

Los Alamos, NM 87545

Attn: J. R. White, K555

W. L. Kubic, K557

K. Pasamehmetoglu, K555

\section{ONSITE}

13 DOE Richland Operations Office

\section{J. J. Davis}

$57-53$

J. M. Gray (10)

G. W. Rosenwald

A. D. Toth

21 Westinghouse Hanford Company

H. Babad

G. S. Barney

G. Galbraith

D. L. Herting

J. O. Honeyman

J. D. Hopkins

J. D. Johnson

J. W. Lentsch (5)

J. M. Light

N. J. McDuffie

R. J. Parazin

D. A. Reynolds

C. A. Rieck

G. J. Rust

J. P. Sederburg

J. E. VanBeek

R. D. Wojtasek
S7-30

T5-12

H2-52

T6-09

S7-81

R2-11

S7-15

S7-15

B4-08

S7-15

H5-49

R2-11

R2-82

T4-01

R2-11

R3-27

S7-84
No. of

Copies

30 Pacific Northwest Laboratory

R. M. Bean

K9-76

S. Q. Bennett

K7-90

P. R. Bredt

P7-25

J. W. Brothers

K5-22

S. A. Bryan

P7-25

A. R. Felmy

K6-82

J. D. Hudson (5)

K7-15

B. M. Johnson

K1-78

L. A. Mahoney

K7-15

F. E. Panisko

P8-34

L. R. Pederson

K2-44

P. A. Scott

C. W. Stewart (5)

P7-43

K7-15

D. M. Strachan

K9-78

J. M. Tingey

P7-25

D. S. Trent

Publishing Coordination

Technical Report Files (5)

Distr. 1 